\title{
Impact of Foreign Direct Investments on Serbian Industry
}

\author{
Article history: \\ Received: 16 March 2017 \\ Sent for revision: 29 March 2017 \\ Received in revised form: 24 May 2017 \\ Accepted: 7 Jun 2017 \\ Available online: 10 October 2017
}

\begin{abstract}
The empirical researches to date on the impact of foreign direct investments (FDI) on the host country were either focused on the overall macroeconomic impact of FDI on exports of the host country or have analyzed the direct contribution of foreign affiliations or looked for spillover effects. By using a mixed model, the method of least squares (OLS) with fixed effects, in the paper has been proved that FDI had a positive effect on the growth of Serbian exports. FDI led to productivity growth in a large number of companies in the economy. At the same time the research conducted at the company level indicates the existence of horizontal and vertical spillover effects. FDI through vertical spillover effects had a positive effect on major suppliers while have led to significant displacement from the market of main competitors.
\end{abstract}

Keywords: foreign direct investments, export, industry

\section{Uticaj stranih direktnih investicija na srpsku industriju}

Apstrakt: Dosadašnja emprijska istraživanja o uticaju stranih direktnih investicija SDI na zemlju domaćina su bila fokusirana na makroekonomske uticaje SDI na izvoz ili su analizirale direktan doprinos stranih aflijacija ili su ispitivale efekat prelivanja. Koristeći mešoviti model metod najmanjih kvadrata sa fiksnim efektima u istraživanju je dokazano da su SDI imale pozitivan

\footnotetext{
${ }^{1}$ University Singidunum, Faculty of Business, Belgrade, Serbia

${ }^{2}$ University Singidunum, Faculty of Business, Belgrade, Serbia, mhadzic@singidunum.ac.rs
} 
Boljanović S., Hadžić M: Impact of Foreign Direct Investments on Serbian Industry

efekat na rast izvoza Srbije. Strane direktne investicje su vodile porastu produktivnosti u velikom broju domaćih kompanija. Istovremeno, istraživanje je vršeno na mikroekonomskom, nivou kompanija ukazale su na horizonatlni I vertikalni efekat prelivanja. SDI kroz vertikalni efekat prelivanja su imale pozitivan efekat na glavne snabdevače, dok su istovremeno uticale na istiskivanje glavnih konkurenata sa tržišta.

Ključne reči: strane direktne investicije, izvoz, industrija.

\section{Introduction}

When a multinational company decides to enter a new market through direct investment in a particular country, it performs a direct transfer of modern technology to its affiliation. Modern technology in the form of modern machinery and equipment and intangible productive assets are essential for foreign affiliation as a comparative advantage over domestic enterprises which have better business contacts and more information on the domestic market. At the same time, the presence of foreign affiliates of multinational companies in the host country accelerates the pace of technological change and the intensity of the adoption of technological knowledge in an indirect way, through spillover effects, which occur on the basis of the diffusion of technology from affiliates to domestic companies.Recent researches for developed and transitory economies are not conclusive about FDI influences on competitiveness of the host country and its export performances, and FDI spillover effects as well.

In the paper, the influence of FDI on the Serbian manufacturing will be investigated through research on the macro and micro level. At the macro level, the level of industry, research will be aimed at identifying the impact of FDI on the export of Serbian manufacturing industry. The research covers the period from 2006 to 2013, data were collected from data base of the Statistical Office of the Republic of Serbia, and National Bank of Serbia. What factors beside FDI had an impact on exports? Through which channels and to what extent foreign investments had impact on exports? These are just some of the questions that should be answered through the research on the macro level.

Research at the micro level, the enterprise level, will be aimed at identifying horizontal and vertical spill-over effects, as well as development trends of privatized enterprises and green-field investment. The research covers the period from 2000 to 2013, data were collected from the Serbian Business Registers Agency (SBRA).Is there any growth of net profit after acquisition? What happened to main competitors after entrance of foreign affiliation on the market, were they driven out of the market? Did major suppliers have benefit 
from cooperation with foreign affiliation? These are just some of the questions that should be answered through research at the micro level.

The scientific goal of the research is scientific explication of the relationship between FDI and the Serbian manufacturing industry with elements of scientific predictions. The aim of the research is to identify the impact of FDI on the export of Serbian manufacturing industry and horizontal and vertical spill-over effects.

\section{LiteratureReview}

Empirical research on the impact of FDI on the host country may be divided on the studies that have focused on the overall macroeconomic impact of FDI on exports of the host country and on those studies that have analyzed the direct contribution of foreign affiliations or looked for spillover effects.

When it comes to overall macroeconomic impact of FDI on exports of the host country, the results of available empirical researches are inconclusive. Horst (1972) came to conclusion of negative impact of US FDI on US manufacturing exports to Canada. In an attempt to investigate the impact of FDI on using annual data from 1970-98, Sharma (2003) analyzed Indian exports in period from 1970-1998 and found no statistically significant evidence of the impact of FDI on exports. On the other hand, some studies found positive effect of FDI on export performance of host countries, as found by O'Sullivan (1993) in Ireland and Blake and Pain (1994) in the United Kingdom.

A large number of studies that have appeared in recent years have focused on the research of the impact of FDI on productivity growth of local enterprises through spillover effects. Research with the help of the econometric models of comparative data and the panel data referred to the developed countries, developing countries and transition economies. First researchs (Caves 1974; Globerman 1979; Blomstrom and Persson 1983) used a model of comparative data and mainly came to the conclusion about the positive effects. The existence of positive spillover effects may have incurred as a result of investment of multinational companies in industries with high productivity. The main objection to this research is that specific industry effects and time effects have not been taken into consideration.

The availability of panel data has allowed researchers to address shortcomings of comparative data usage. Panel data among other things, have enabled researchers to take into account the time lag required for domestic companies to absorb the spillover effects. Results obtained using panel data were pretty much different from the initial results obtained using comparative data. Using panel data led to the conclusion about the negative 
or negligible effect (Aitken and Harrison 1997, Djankov and Hoekman 1996; Konings 2000). Some of the research using panel data showed the existence of positive effects or assuming certain factors such as absorption capacity (Kinoshita 2001, Girma 2005) and the level of technological gap between foreign and domestic companies (Kokko,Tansini and Zejan 1994; Basile,Castellani and Zanfei 2003). In a detailed review of the research on the spillover effects related to FDI, Gorg and Strobl (2004) concluded that the results of productivity spillover does not depend on whether data at the level of industries or companies were used but on whether methods of comparative data or panel data were used. Of the 40 studies, in 19 there has been a statistically significant conclusions about the existence of positive spillover effects, 15 studies found no significant spillover effects and 6 studies found evidence of negative spillover effects. As explanation for this phenomenon, some researchers believe that many researchs have been using data with excessive levels of aggregation making spillover effects much more difficult to detect, which does not mean they don't exist. Also, spillovers may simply depend on some of the characteristics of host country, the type of FDI prevailing in the country, which lead to different results for different countries.

The lack of positive horizontal spillover effects using panel data forced the researchers to search for possible vertical spillover effects related to FDI. These studies are based on the belief that domestic companies which are vertically (up or down) associated with foreign affiliation have the benefits of this cooperation. Variables for detecting vertical spillover effects are designed using input-output table. Some studies have found evidence of positive vertical spillover effects (Schoors and van der Tol (2002) for Hungary, Javorcik, Saggi and Spatareanu (2004) for Lithuania; Blalock and Simon (2009) for Indonesia. Other studies, however, have come to the different results. Tytell and Yudeva (2005), who explored the Russian industrial enterprises found negative vertical downward and upward effects. Merlevede and Schoors (2007) came to the conclusion about the positive vertical spillovers upward while when it comes to the downward effects (to suppliers), positive effects were found only in the case of export-oriented sectors.

Literature overview is suggesting that the initial studies based on the model of comparative data came to the conclusion about the positive horizontal spillovers while most research based on panel data come to a conclusion about the negative or neglecting spillover effects. Based on the results of previous research, it can be concluded that the evidence of positive spillover effects are very weak. 
Boljanović S., Hadžić M: Impact of Foreign Direct Investments on Serbian Industry

\section{Methodology}

Research of the impact of FDI on the Serbia's export was done on the basis of the model created by Vuksic (2005):

$\operatorname{lnEXjt}=\alpha j+\beta 1+\beta 2 \ln P D j t+\operatorname{InULCjt}++\beta 3 \operatorname{lnREERt}+\beta 4 \operatorname{lnlj}(\mathrm{t}-1)+\beta 5 \ln$ FDlj

The variables are as follows: dependent variable InEX is the natural logarithm of real exports, the independent variables are the natural algorithms of productivity index (InPD), unit labour costs (InULC), the real effective exchange rate (InREER), domestic investment (LnI) and stock of FDI (InFDI). The constant aj denotes specific fixed effects of industry branch, while $\mathrm{j}=1.21$ means different industries, and t denotes different years (from 2006 to 2013 in the case of study in the paper).

As can be seen from the model, domestic investment and the stock of FDI are used with one year time - lag of. This can be explained by the fact that it takes some time for new investments to become effective. In the case of FDI, the use of data with a time - lag should also help to avoid the problem of simultaneity between the variables of exports and FDI. Using stock of FDI rather than annually FDI inflow should also contribute in solving this problem. The FDI stock should also better show the importance of the presence of foreign capital in a particular branch of industry, which is important since it can cause technology spill-over effects. If the inflow of foreign capital was used as a variable in the model, it is possible that there is a significant inflow of foreign capital in the beginning of the period and after that there is no inflow of new foreign capital in the industry. In this way, the value of this variable would be 0 for all the years when there was no new inflow of foreign capital, which would totally ignore the strong presence of foreign capital that has been invested, which is a potential source of significant positive spill-over effects.

There is a potentially significant variable which is not included in the above model - the export market. The reason that it is left out is simple - it is very difficult to measure this variable. Using GDP growth of countries of export destination turned out to be insignificant because the use of this indicator doesn't cover different export tendencies of various export sectors.

These model specifications are modifications and extensions of the model estimates on the aggregate, macroeconomic level, which were presented by Sun (2001) and Zhang and Song (2000). Both papers were using the natural logarithm of real exports as the dependent variable and the logarithm of the FDI stock with a lag of one year. Sun (2001) also used domestic investment, and the real effective exchange rate was included in both papers as an 
independent variable. Productivity and unit labour costs are added as variables, because they are expected to be important indicators of the competitiveness of the export industry (Vuksic, 2005, p.20).

\section{The Impact of FDI on Serbian Exports}

In the study of the impact of FDI on export of Serbia's manufacturing industry, the data in the period from 2006 to 2013 were used. Data refer to the 23 branches of the processing industry by the National Classification of Economic Activities (NCEA). Data on exports, the average monthly gross wages, gross added value (GVA), gross investment in fixed assets, number of employees and the producer price index have been collected from data base of the Statistical Office of the Republic of Serbia, while the data on the real effective exchange rate and the stock of FDI have been from sources of National Bank of Serbia. The index of labor productivity $(P)$ for each branch of industry is calculated as the ratio of GVA and the number of employees (E) in the industry.

$$
P_{j t}=B D V_{j t} / E_{j t}
$$

The index of unit labour costs (ULC) is constructed as in Carstensen and Toubal (2004), as multiplication ratio of the average monthly gross wage (BP) and the total number of employees (E) with GVA in industry $i$ in time interval t.

$$
\operatorname{JTR}_{\mathrm{jt}}=B \mathrm{PP}_{\mathrm{jt}}{ }^{*} E_{\mathrm{jt}} / B D V_{\mathrm{jt}}
$$

Data on exports, FDI stock, wages, GVA, gross investment in fixed assets are seasonally adjusted using the index of producer prices (values related to a cumulative level of FDI have been converted from dollars into dinars (RSD) and then seasonally adjusted). The base year for all of the data and other indexes is 2006 .

Figure 1 shows the movements of nominal and real exports and nominal and real FDI stock in the period 2006 - 2013. Looking at the movement of real exports and real stock of FDI during the period covered by the survey, great similarity can be observed, since the export growth follows the growth of cumulative level of FDI. The exceptions are year of 2009 and 2013. In 2009, as can be seen from the figure, a slight increase in the real FDI stock is accompanied by the fall of real exports, but this can be explained by the outbreak of the global economic crisis in late 2008. On the other hand, in 2013, the stagnating level of FDI stock is accompanied by significant growth in real exports. 
Boljanović S., Hadžić M: Impact of Foreign Direct Investments on Serbian Industry

Figure 1. Exports and FDIstock (million of RSD) (2006-2013)

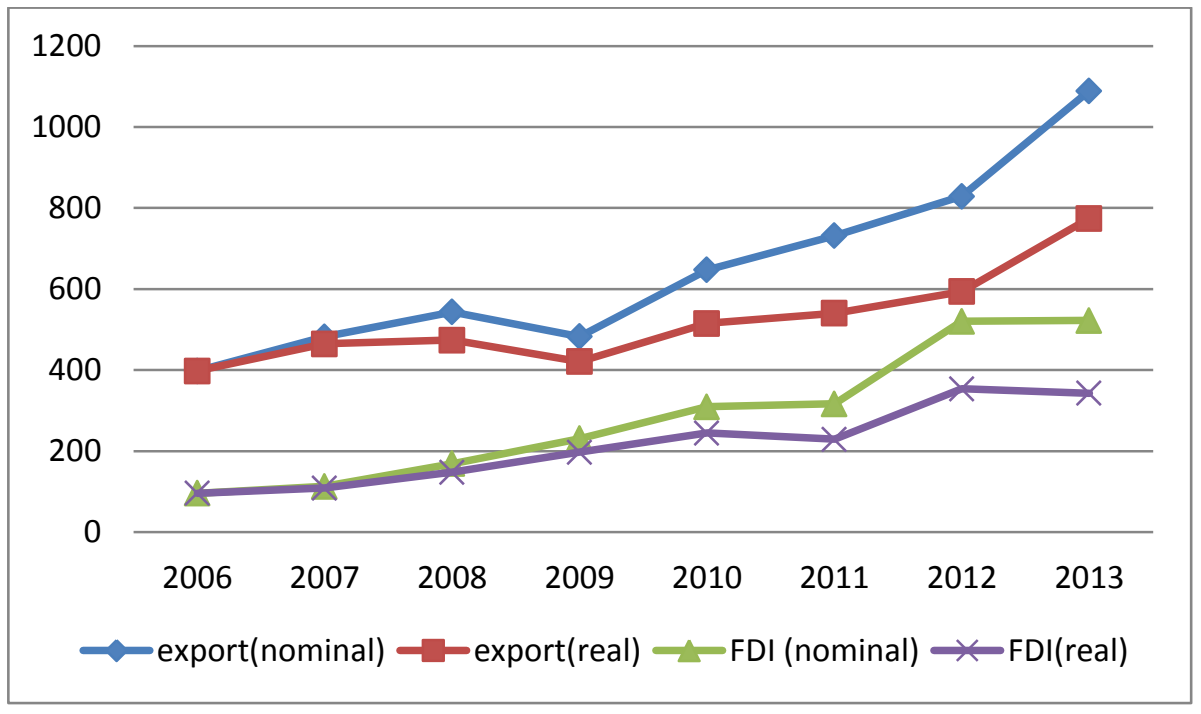

Source: Author's calculation

Figure 2 shows trends in other relevant variables for the whole manufacturing industry: the gross investment, productivity, real effective exchange rate, unit labour costs. Productivity, the real effective exchange rate and unit labour costs are expressed in indices (the base year is 2006) on the right $y$-axis, while exports and gross fixed capital formation are expressed in millions of RSD and their movement can be observed on the left side of the $y$ - axis.

Gross investments in fixed assets had an upward trend in the period 20062008. With the advent of the global economic crisis it decreased, which is interrupted in 2010, since when there is a steady growth which was particularly noticeable in 2012. Productivity tends to increase in the reporting period (particularly noticeable increase in productivity in 2008) with the exception of 2009 and 2011 when there was a slight decrease in productivity. Productivity growth should have a positive impact on export growth. The real effective exchange rate (defined so that the increase in the index means real depreciation), had decline in 2007 followed by a slight growth (dinar depreciation as a result of the advent of the global economic crisis), which is interrupted in 2011. At the same time labour costs show a fairly volatile movements in the reporting period, in 2013 increase in the index was recorded, which should have a negative impact on the export trend. 
Boljanović S., Hadžić M: Impact of Foreign Direct Investments on Serbian Industry

Figure 2: Exports, gross capital formation, productivity, real effective exchange rate, unit labor costs (millions RSD and indexes) (2006-2013)

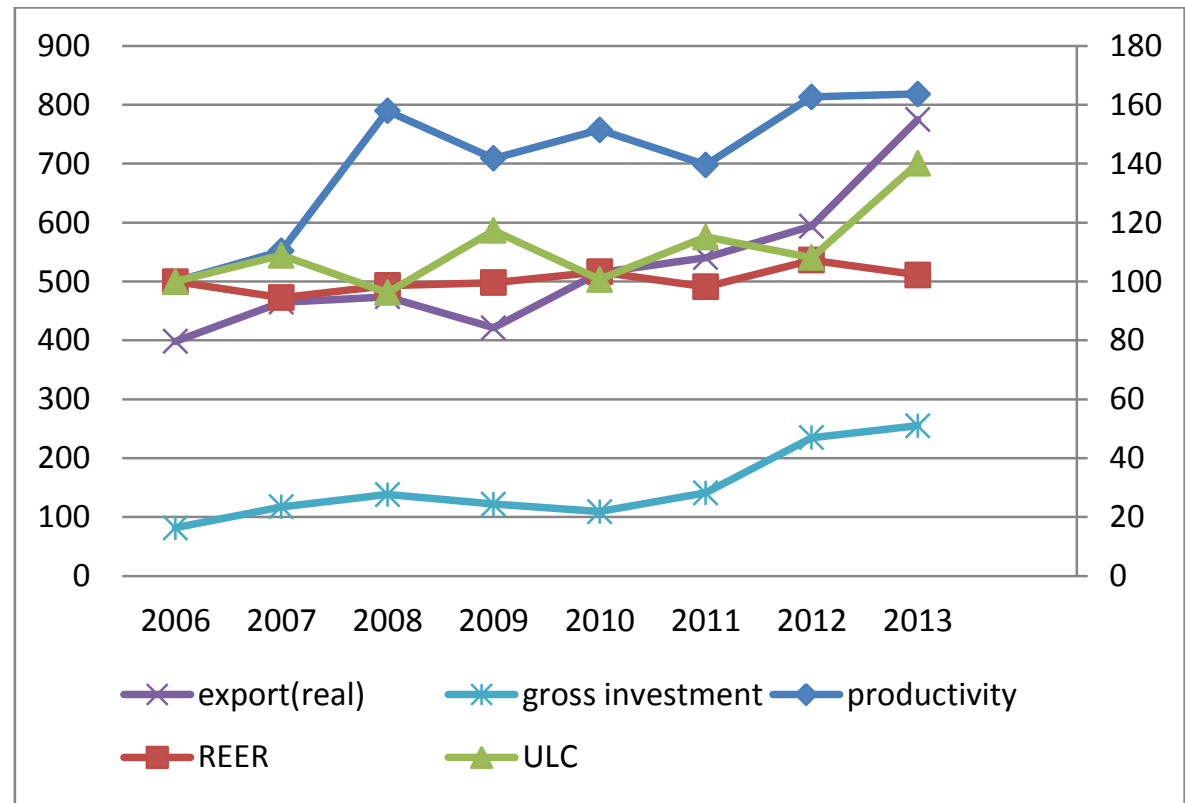

Source: Author's calculation

In Table 1 data on exports, the FDI stock, productivity, unit labor costs and gross investments by industry are presented. Average export value of FDI stock and gross investment are in millions RSD while average value of productivity and unit labour costs are in index values.

From the table, it can be seen that only one branch of industry (base metals) recorded negative growth in real exports during the period. In this industry, the mean value and increase in cumulative level of FDI were at a higher level than in most other industries, so we can conclude that in the case of this industry FDI haven't had a positive impact on export growth (although these trends almost certainly have been affected by the trends in the world market and the suspension of production at the steelworks in Smederevo). It is significant that this industry recorded the highest growth in unit labour costs.

The highest growth in real exports was recorded in industry of motor vehicles and trailers $(70.67 \%)$, manufacture of tobacco products (34.04\%) and in metal production $(24.65 \%)$.In the case of the production of motor vehicles and trailers the second largest increase in the FDI stock was recorded (an 
average of $134 \%$ per year). So, in this case we can talk about the positive impact of FDI on the growth of exports. Besides that, the highest average growth of cumulative level of FDI was recorded in the manufacturing of coke and refined petroleum products (in this branch there was a moderate average growth in real exports of $13.24 \%$ ) and in manufacture of other transport equipment (which recorded an average growth of exports $24.43 \%$ ). The highest average value of the FDI stock was recorded in the case of the production of food and drink, this industry has the second highest average value of total exports.

The highest average productivity growth was recorded in the production ofmotor vehicles and trailers (36.93\%) and in the manufacturing of coke and refined petroleum products $(34.98 \%)$. Those two industries have recorded the highest average growth of FDI stock, so it is clear that foreign investment had a positive impact on productivity. Negative average productivity growth was recorded in the case of only one branch of industry (food and drink), which has quite high FDI stock.

The highest average growth in unit labour costs was recorded in the manufacturing of basic metals and textile yarn and fabrics industry. Both sectors have recorded relatively high average growth of FDI stock. On the other hand, the greatest average reduction in unit labour costs of $15.48 \%$ was observed in the case of those industries which recorded the highest average growth of FDI stock - production of coke and refined petroleum products.

Three branches of industry recorded a negative average growth of gross investment: food products and beverages, chemicals and chemical products, rubber and plastic. With the exception of food products and beverages, the other two industries had relatively low levels of growth in FDI stock. The highest average growth in gross investments was recorded in the case of motor vehicles and trailers in which, as already was noted, the second largest increase in the average level of FDI stock was recorded.

\section{Table 1 Appendix}

Table 2 shows the correlation coefficients between variables analyzed. The maximum value of the correlation coefficient is 0.619 between exports and FDI stock (strong positive correlation), which indicates that FDI contributed to the increase in exports. Exports were also strongly positively correlated with employment and gross investments, which suggests that the industries that have recorded significant export had more employees and the higher level of gross investments compared to other industries. FDI stock is in a relatively 
Boljanović S., Hadžić M: Impact of Foreign Direct Investments on Serbian Industry

strong positive correlation with the number of employees and somewhat milder positively correlated with the level of gross investments.

Table 2. Correlations between variables

\begin{tabular}{|l|c|c|c|c|c|c|}
\hline & FDI & $\begin{array}{c}\text { Produc } \\
\text { tivity }\end{array}$ & $\begin{array}{c}\text { Unit } \\
\text { labor } \\
\text { costs }\end{array}$ & REER & Employment & $\begin{array}{c}\text { Gross } \\
\text { investment }\end{array}$ \\
\hline Export & 0.619 & 0.019 & 0.269 & 0.085 & 0.611 & 0.575 \\
\hline FDI & & -0.123 & 0.184 & 0.200 & 0.569 & 0.394 \\
\hline Productivity & & & -0.250 & 0.196 & -0.175 & 0.346 \\
\hline $\begin{array}{l}\text { Unit labor } \\
\text { costs }\end{array}$ & & & -0.013 & 0.066 & -0.032 \\
\hline REER & & & & & -0.078 & 0.071 \\
\hline Employment & & & & & & 0.507 \\
\hline
\end{tabular}

Source:Author's calculation

The correlation coefficient, which is even more noteworthy, is between the level of gross investment and employment that is intuitively clear (higher gross investments mean higher employment). Other correlation coefficients have negligible value. So, considering correlation coefficients, it can be concluded that FDI had a positive effect on the growth of Serbian industrial export, increase in employment and increase in the level of gross investments. At the same time, there is no evidence that FDI contributed to the reduction of unit laboru costs.

Following models were estimated:

$$
\begin{aligned}
& \ln E X j t=\alpha j+\beta 1 \ln P D j t+\beta 2 \operatorname{lnULCjt}+\beta 3 \operatorname{InREERt} \\
& \operatorname{lnEXjt}=\alpha j+\beta 1 \ln P D j t+\beta 2 \ln U L C j t+\beta 3 \operatorname{InREERt}+\beta 4 \operatorname{Inlj}(t-1) \\
& \ln E X j t=\alpha j+\beta 1 \ln P D j t+\beta 2 \ln U L C j t+\beta 3 \ln R E E R t+\beta 5 \ln F D l j(t-1) \\
& \operatorname{InEXjt}=\alpha j+\beta 1 \ln P D j t+\beta 2 \ln U L C j t+\beta 3 \operatorname{InREERt}+\beta 4 \operatorname{Inlj}(\mathrm{t}-1)+\beta 5 \operatorname{InFDIj} \\
& (\mathrm{t}-1)
\end{aligned}
$$

Table 3presents the results of the model assessment. It can be concluded that FDI had a positive effect on the growth of Serbian exports. When all the variables were included in the model, the increase in the FDI stock of $1 \%$ leads to an increase in exports of $0,035 \%$, with significance level of $5 \%$. When gross investments were not included in the model, the impact of FDI is even more powerful, increase in the FDI stock of $1 \%$ leads to an increase in 
Boljanović S., Hadžić M: Impact of Foreign Direct Investments on Serbian Industry

exports of $0.149 \%$, with significance level of $1 \%$. The level of gross investments has an even stronger impact on exports, increase in gross investment of $1 \%$ leads to an increase in exports of $0.240 \%$ with significance level of $1 \%$.

The positive impact of FDI on exports is also manifested through productivity when FDI and gross capital formation were not included in the model (model 1 ). Increase in productivity of $1 \%$ leads to an increase in exports of $1.294 \%$ with significance level of $1 \%$. The positive impact of FDI on productivity is in line with the results of research conducted by Vuksic (2005) and Škudar (2004). It seems that the productivity is the channel through which FDI influenced better export performances of Serbian industry.

Real effective exchange rate haven't had a major impact on exports, as in all models, the impact of the real effective exchange rate on exports is not statistically significant. Unit labor costs were statistically significant in the model in which FDI are not included. The increase in unit labor costs of $1 \%$ leads to a reduction in real exports of $0.021 \%$.

The obtained results are in line with the results obtained by Vukšić (2005) in his research on the impact of FDI on exports of the Croatian processing industry. In the case of Croatia, the increase in FDI of $1 \%$ led to an increase in exports of $0.09 \%$, which is a somewhat stronger impact than in the case of Serbia. In the case of Croatia, unit labor costs have proved to be a more important factor in determining exports than in case of Serbia.

Table 3: The results of model assessment

\begin{tabular}{|c|c|c|c|c|}
\hline \multicolumn{5}{|c|}{$\begin{array}{l}\text { Dependent variable: Exports } \\
\text { The method of assessment: Fixed effects - OLS estimation }\end{array}$} \\
\hline & Model 1 & Model 2 & Model 3 & Model 4 \\
\hline Constant & $\begin{array}{l}-385.266 \\
(470,432)\end{array}$ & $\begin{array}{c}-34,864 \\
(266,439)\end{array}$ & $\begin{array}{c}199,103 \\
(369,868)\end{array}$ & $\begin{array}{l}-120,136 \\
(268,140)\end{array}$ \\
\hline Productivity & $\begin{array}{l}1,294^{* * *} \\
(0.289)\end{array}$ & $\begin{array}{c}0,063 \\
(0,177)\end{array}$ & $\begin{array}{c}0,289 \\
(0,245)\end{array}$ & $\begin{array}{c}0,117 \\
(0,178)\end{array}$ \\
\hline Unit labor costs & $\begin{array}{l}0,164 \\
(0.304)\end{array}$ & $\begin{array}{c}-0.021^{\star \star \star} \\
(0.172)\end{array}$ & $\begin{array}{l}-0.132 \\
(0,238)\end{array}$ & $\begin{array}{c}0,021 \\
(0,172)\end{array}$ \\
\hline REER & $\begin{array}{c}3,657 \\
(4,770)\end{array}$ & $\begin{array}{c}1,504 \\
(2,697)\end{array}$ & $\begin{array}{l}-1,297 \\
(3,737)\end{array}$ & $\begin{array}{l}2,349 \\
(2,713)\end{array}$ \\
\hline Gross investment & & $\begin{array}{l}0,209^{* * *} \\
(0,011)\end{array}$ & & $\begin{array}{l}0,240^{\star * \star} \\
(0,020)\end{array}$ \\
\hline FDI & & & $\begin{array}{l}0,149^{* \star *} \\
(0,015)\end{array}$ & $\begin{array}{l}0,035^{\star *} \\
(0,019)\end{array}$ \\
\hline
\end{tabular}

Standard errors are shown in parentheses. ${ }^{* *},{ }^{* *},{ }^{*}$ indicate significance level of 1,5 and $10 \%$

Source: Author's calculation 


\section{The Effect of FDI on Spill-over effects at the Micro level}

Blomstrom and Kokko (1997) identified the four channels through which spillovers materialize: demonstration effect, vertical connection, the effect of training and the effect of competition. The demonstration effect is reflected in stimulation of domestic companies to improve their production methods based on the exposure to superior technology of multinational companies. Vertical connection is the establishment of direct relations between companies engaged in complementary activities that are beyond the pure market transactions (Lall, 1980). Training and improving the skills of employees at all levels and research and development efforts of foreign affiliates combined with mobility of work force are very important source of potential spill-overs. The entrance of foreign affiliate on the domestic market raises the level of competition and performs competitive pressure on domestic companies to introduce new technological solutions and improve production efficiency in order to maintain its position in the market and in order to survive.

Investigation of the influence of FDI at the macro level was completed with research at the micro level, the level of enterprise. In the random sample of 40 foreign-owned companies in Serbia, a survey was made to identify the main competitors and suppliers. After identifying them, the total sample consisted of 70 companies - 40 foreign-owned companies, 15 main competitors and 15 major suppliers. For the selected sample, data were collected on sales, cost of sold goods, cost of materials, net profit, total equity, total assets and number of employees in the period of 2000-2013. The data were seasonally adjusted, as a basic year2000 was used. Data were collected from the Serbian Business Registers Agency (SBRA). The goal of the data collection is to explore trends in the number of employees, sales revenue, productivity, net profit, return on equity and return on assets in the case of purchased companies by foreign owners (acquisitions), the newly built production facilities (green-field investment), the main competitors in the market and major suppliers.

Figure 3 shows the average percentage change in the number of employees in the case of acquisitions, green-field investments, the main competitors in the market and major suppliers.

The year of acquisition by foreign owners (in the case of acquisitions), the year in which production started in new plants (in the case of green-field investments) and the year of acquisition and production start (in the case of main competitors and major suppliers) was taken as a base year ( $\mathrm{t}$ ).

As can be seen from the figure 3 in the case of acquisition, a declining trend in the number of employees started even before acquisition ( 3 years prior to the acquisition, companies in the sample had on average $20 \%$ more 
employees than in the year of the acquisition) carried on after the purchase of the company by a foreign owner. Purchased companies had on average $13 \%$ less employees after three years and $24 \%$ after six years. Only $23 \%$ of purchased companies had more employees after six years than in the year of acquisition, while most saw a drastic drop in the number of employees.

Figure 3. Average percentage change in the number of employees

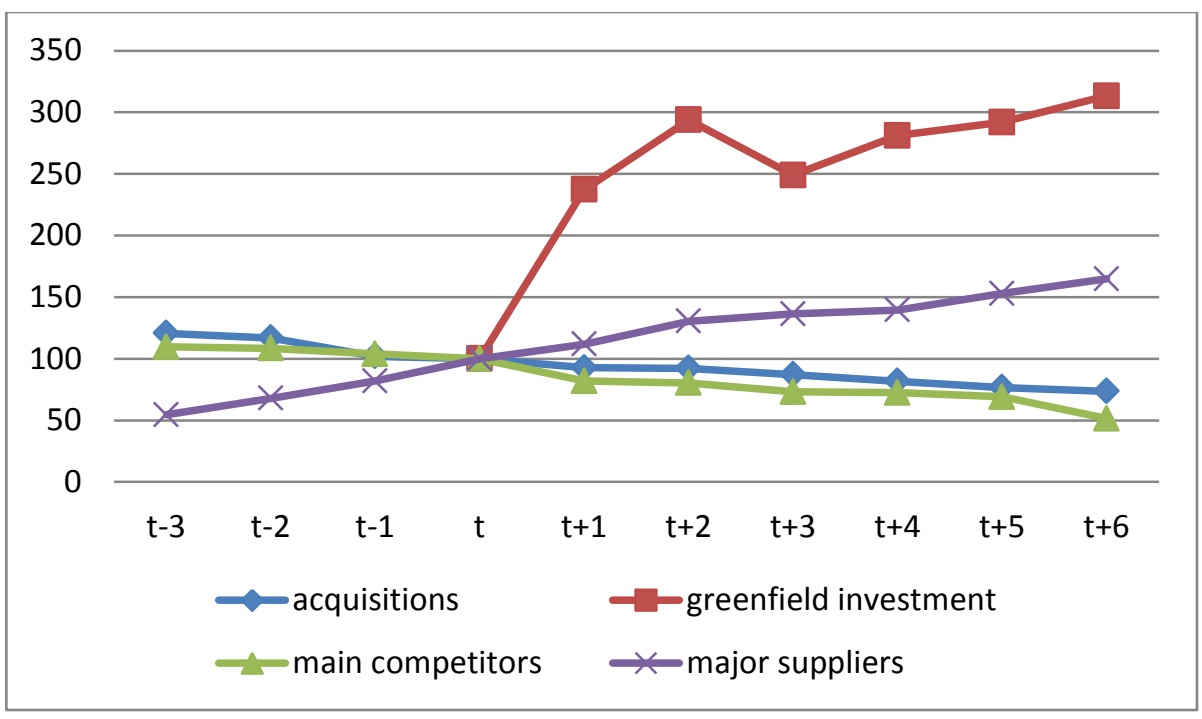

Source: Author's calculations based on data provided by the SBRA

In the case of green-field investments the impact on employment is a clear, as opening of new plants create jobs and in the event of an increase in production volume, the number of employees is increasing over the years, as it turned out on the selected sample. Already after the first year, the number of employees increased 2.3 times on average, which was followed by steady, but slower growth (6 years from the start of the production number of employees was on average 3.13 times higher than in the base year). Only one company in the sample has recorded fewer workers six years after the start of business operations in relation to initial number of employees.

In the case of main competitors, after a slight initial drop in the period before the advent of foreign investors in the market, there is a sharp drop in the number of employees in the following years after the appearance of a foreign company in the market. On the average, three years before the appearance of a foreign company, competitors had $9.6 \%$ more workers than in the base year, while only one year after the entry of foreign companies into the market 
they had $20 \%$ fewer employees than in the base year. In the sixth year after the entry of foreign companies into the market, main competitors had only $51.46 \%$ of the employees in the base year. On the basis of those findings it can be said that there were a negative horizontal spill-overs relating to staff reductions within main competitors.

In the case of the major suppliers, there is an increasing trend in the number of employees. This trend existed in the years prior to entrance of the foreign companies in the market (three years before the acquisition, suppliers had on average $54.5 \%$ of workers in the base year) and continued at a similar pace after acquisition. Three years after the acquisition the number of workers has increased $36.3 \%$, in the sixth year following the acquisition $64.7 \%$ compared to the base year. Only one supplier in the sample had a slight decrease in the number of employees in the sixth year following the acquisition compared to the base year. So, we can talk about the existence of vertical positive spillover effects, but it is difficult to fully mark it off with the existing trend in the time before the entrance of a foreign investor.

It can be concluded that in the case of acquisition there was a decrease in the number of employees, in the case of green-field investments there was a creation of new jobs and increase in the number of employees with the increase in production volume, in the case of main competitors a negative horizontal spill-over effects were recorded and with major suppliers mild positive vertical spill-over effects were recorded.

Figure 4 shows the average percentage change in sales revenue in the case of acquisitions, green-field investments, the main competitors in the market and major suppliers.

As can be seen from the figure 4, in the case of acquisitions, there is increasing trend of sales, which existed even before the acquisition. Three years before the acquisition, average sales revenue was $28 \%$ onlycompared to the revenue in the year of acquisition, two years after the acquisition it was higher by $87 \%$ than in the base year and in the third year after the acquisition it was 2.14 times higher than in the base year. Only $9 \%$ of the sample has not had higher sales in the third year from acquisitions compared to the base year. In the coming years, sales have stabilized, with the tendency of slight increase. In the sixth year after the acquisition sales revenue was 2.24 times higher compared to the base year.

In the case of green-field investments, average sales growth compared to the base year is drastic, but it is understandable given the great potential to improve the production process, productivity, quality and characteristics of the products, distribution channels and possibility to penetrate new markets, make better position on existing market, better inform customers about the products that company offers. Already after one year from the start of 
production, sales revenues were 15.3 times higher than in the base year, in the third 21.8 times higher, after six years from the start of production even 14.88 times higher compared to the base year.

Figure 4. Average percentage change in sales revenue

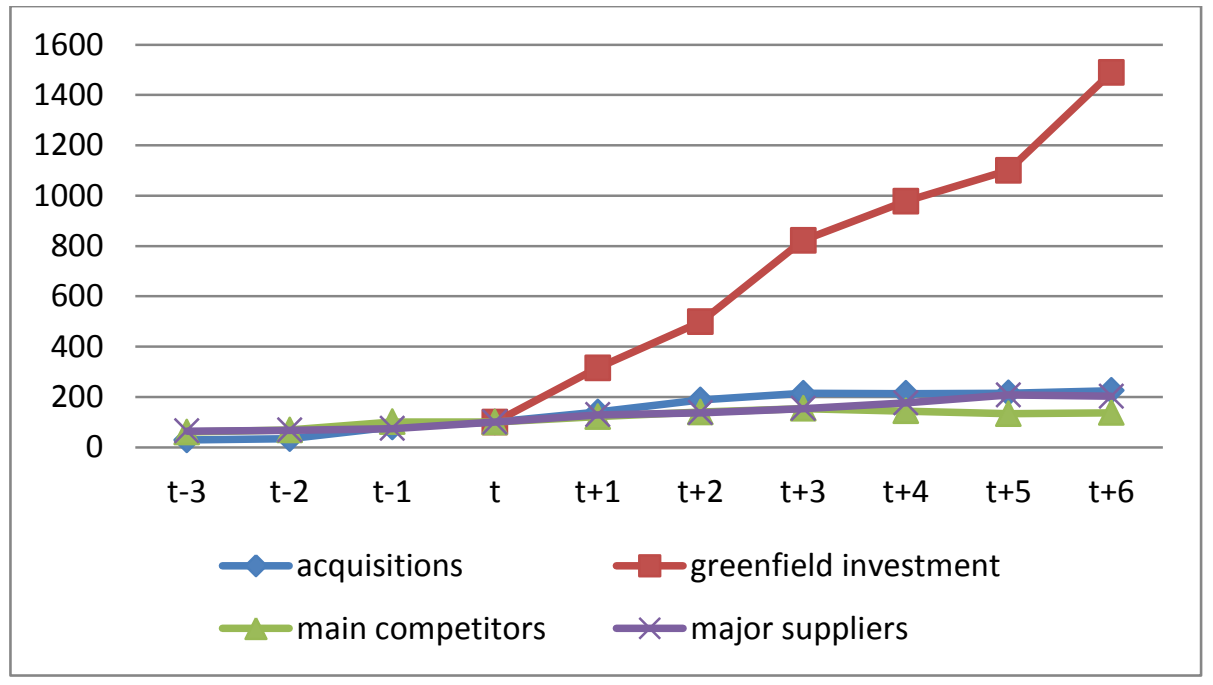

Source: Author's calculations based on data provided by the SBRA

In the case of major competitors, there is a tendency of moderate sales growth up to three years from the entry of foreign companies into the market. Three years before entrance of foreign companies in the market, the average sales revenues were $60 \%$ compared to the base year, three years after the entry of foreign companies into the market sales revenues were $53 \%$ higher than in the base year (only $25 \%$ of the sample had lower sales in the third year compared to the base). Regardless that growth of sales revenue was slower in relation to acquisitions, this suggests that the main competitors had enough market space and opportunities for growth and development. After the third year from the entry of foreign companies into the market, a decline in the average income of sales started, which by the sixth year of the entry of foreign companies into the market was only $37 \%$ higher in comparison to the base year $(37.5 \%$ of the sample had lower sales than in the base year). For this reason, we can talk about the negative horizontal spill-over effects, as measured by extrusion of main competitors from the market.

In the case of the major suppliers, there is a trend of continuous increase in sales revenues, which is slightly slower compared to the acquisition. Three 
years before the entrance of foreign companies on the market, the average income from sales for suppliers were $64 \%$ compared to the base year, one year after the entry of foreign companies into the market it was $28 \%$ higher, and in the third year, 53\% higher compared to the base year (the same as in the case of the main competitors). Unlike competitors who have experienced a decrease in revenues from sales after the third year, suppliers continued to increase sales revenue. In the sixth year from the entry of foreign companies into the market, they had a 2.2 times higher sales than in the base year (all companies in the sample had higher sales in sixth than in the base year).

Figure 5. The average percentage change in productivity

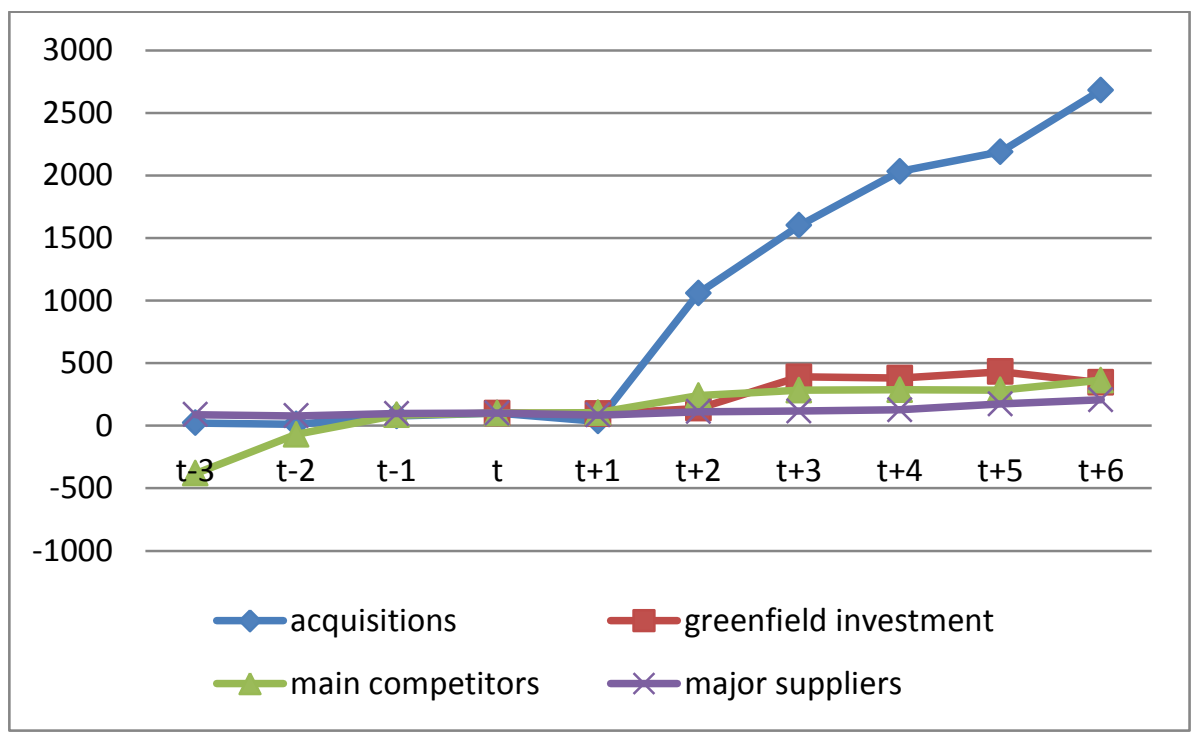

Source: Author's calculations based on data provided by the SBRA

Thus, it can be concluded that in the case of acquisitions, greenfield investments and major suppliers, there is a trend of sales growth, while in the case of main competitors there are negative horizontal spill-overs, which are reflected through the displacement from the market and in a drop in revenues from sales after the third year from the entry of foreign companies on the market.

Figure 5 shows the average percentage change in productivity in the case of acquisitions, green-field investments, the main competitors in the market and major suppliers. 
Labour productivity $(\mathrm{P})$ is measured by commonly used methods, as add value ratio (VA) per worker $(\mathrm{N})$. Added value is calculated by the method of subtraction; from sales revenues the cost of materials (CM) and the cost of sold goods (VG) were deducted.

$$
P=V A / N=S-(C M+V G)
$$

As can be seen from the figure 5 , in the case of acquisitions there is a sharp improvement in average labor productivity. This trend was also present before the acquisition, three years before the acquisition by a foreign company, productivity was only $22 \%$ compared to the base year. The decline in productivity was recorded only in the first year after the acquisition and it can be explained by organizational changes and changes in the production process (restructuring process). In the second year after the acquisition, productivity was 10 times higher than in the base year, and in the sixth year following the acquisition as much as 26 times higher than in the base year (only one company from the sample recorded lower productivity than in the base year). This suggests that the availability of specific resources that foreign companies possess have allowed privatized enterprises to improve their productivity drastically. A part of Productivity growth can be partially explained by better organization of work processes and reduced number of employees.

In the case of green-field investments, there is also a growing trend of productivity. This is particularly noticeable after the second year of the production start when labor productivity was 37\% higher than in the base year and in the fifth year it was 4.3 times higher than at the beginning. In the sixth year there was a slight drop in productivity in comparison to the previous year, but $18 \%$ of the sample in that year only had lower productivity compared to the base year.

In the case of major competitors, there is also an upward trend of labour productivity. In the years preceding the entry of foreign companies into the market, competitors have registered negative productivity (negative added value, sales revenues were lower than the sum of the cost of materials and the cost of sold goods), but after the entrance of foreign companies to the market, competitor's productivity began to grow dramatically, especially in the second year after the entry of foreign companies into the market. For example, in the second year after the entry of foreign companies into the market labour productivity was 2.4 times higher than in the base year, and in the sixth year 3.6 times higher than in the base year. So, we can talk about the positive horizontal spillovers effect.

In the case of major suppliers, there is also a growing trend of average productivity, which is moderate in relation to the acquisitions, 
greenfieldinvestments and main competitors. Three years before the appearance of foreign companies to the market, the average productivity was $88 \%$ compared to the base year, three years after the entry of foreign companies to the market, it was $16 \%$ higher compared to the base year. In the sixth year it was 2.06 times higher than in the base year. In this case we can talk about the positive vertical spillovers.

Based on the above findings, it can be concluded that acquisitions, green-field investments, main competitors and major suppliers recorded growth of labour productivity. The highest growth in labour productivity was recorded in the case of acquisition, as a result of specific resources which foreign companies posses, like modern organizational methods and improvement of the production process. In the case of main competitors, there was a positive horizontal and in the case of the major suppliers the vertical positive spillover effects.

Figure 6 shows the average percentage change in net profit in the case of acquisitions, green-field investments, main competitors in the market and major suppliers.

Figure 6. Average percentage change in net profit

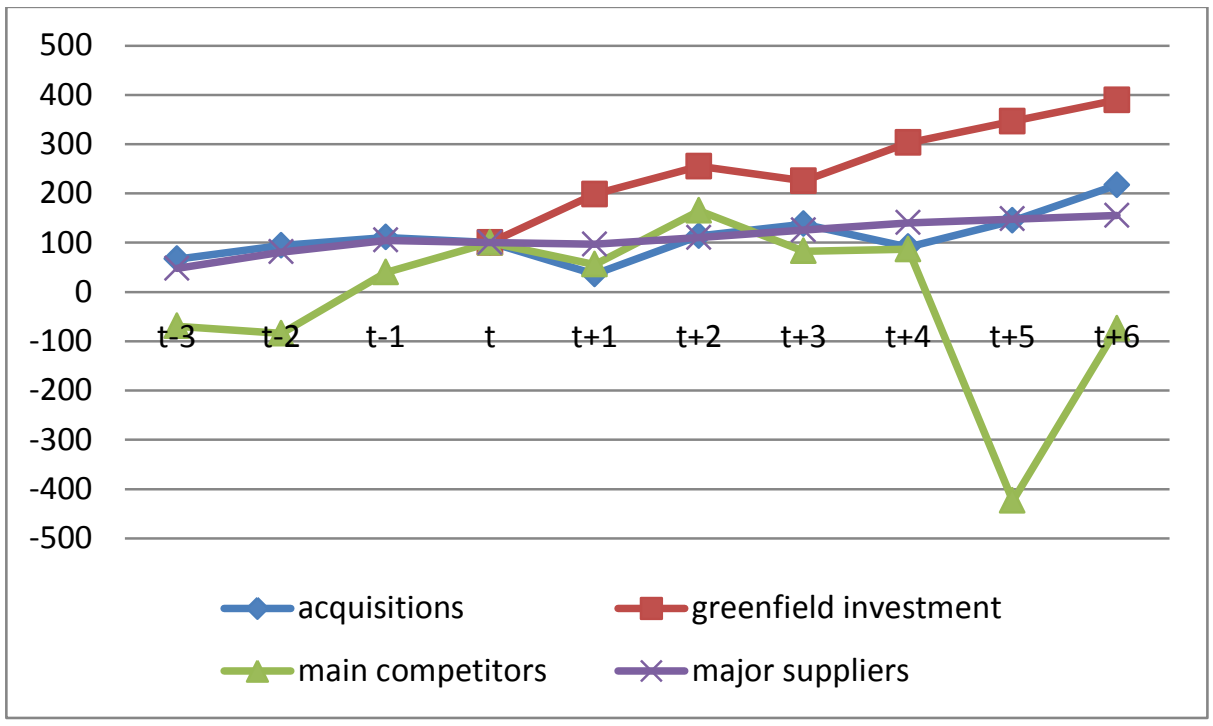

Source: Author's calculations based on data provided by the SBRA

As can be seen from the figure 6 , in the case of acquisitions, a trend of increasing net profit exists. Three years before the acquisition, the net profit 
was $66 \%$ compared to the base year, a year before the acquisition it was $10 \%$ higher than in the base year. After the first year from the acquisition there was a decline in net profit, which amounted to only $35 \%$ compared to the base year, but after that there is a strong upward trend in net profit, which in the sixth year was even 2.17 times higher than in the base year. The growth in net profit of the foreign companies has implications on the repatriation of profits and income account of the current account balance.

In the case of green field investments, there is also a trend of growth of net profit. A high increase in net profit is due to improvement of distribution channels, penetration of new markets, better positioning on existing markets and customers became informed better about the products that the company offers. In the first year after starting the production, average net profit was $98 \%$ higher than in the base year, in the fourth year it was three times higher even, and in the sixth 3.89 times higher than in the base year.

At the same time in the case of main competitors there is an opposite trend with respect to acquisitions and green field investments, because there is a trend of decreasing net profit. In the years preceding the entry of foreign companies to the market, there was a trend of growth in net profit (initially average net profit was negative, most of the companies in the sample have recorded losses), but the growth trend stopped with the entry of foreign companies to the market. After the first year from the entry of foreign companies to the market, competitors have achieved only $55 \%$ of the net profits compared to the base year. After stabilizing in the next two or three years there was a sharp drop in net profit in the fifth and sixth year, when again negative average net profit was recorded $(55.5 \%$ of the sample recorded loss). From those facts it can clearly be concluded that there were negative horizontal spillovers, which are reflected in the displacement from the market and the reduction of net profit.

In the case of the major suppliers there is a trend of moderate growth in net profit which existed before the entry of foreign companies into the market. Three years before the entrance of foreign firm to the market average net profit of suppliers was $47 \%$ compared to the base year, three years after the entry of foreign companies on the market it was $25 \%$ higher compared to the base year and in the sixth year 55\% higher than in the base year (only $25 \%$ of the sample had lower profits in the sixth year compared to the base year). In this case we can speak of a moderate positive vertical spillover effects.

Based on the above, it can be concluded that acquisitions and green field investments recorded a significant growth in net profit, while main competitors recorded fall in net profit (negative horizontal spillovers) and major suppliers recorded moderate growth in net profit (moderate positive vertical spillovers). 
Figure 7 shows the average change in the rate of return on equity in the case of acquisitions, green field investment, the main competitors in the market and the major suppliers. This is also the first graph in which it makes sense to make a direct comparison between different types of investments.

From the figure 7 , it can be seen that in the case of acquisition it is not possible to observe the appropriate trend, since the movement of the average rate of return on equity (ROE) is quite volatile. A year before acquisition average ROE was 17.7, in the year of acquisition it reached the lowest value in the reporting period -1.1 . In the first three years after the acquisition, ROE had a growing trend, maximum has been in the third year when the average ROE was 21.2 (companies with such ROE are considered attractive for investments) and over $70 \%$ of the sample had a higher ROE than in the base year.

Figure 7: The average change in the rate of return on equity

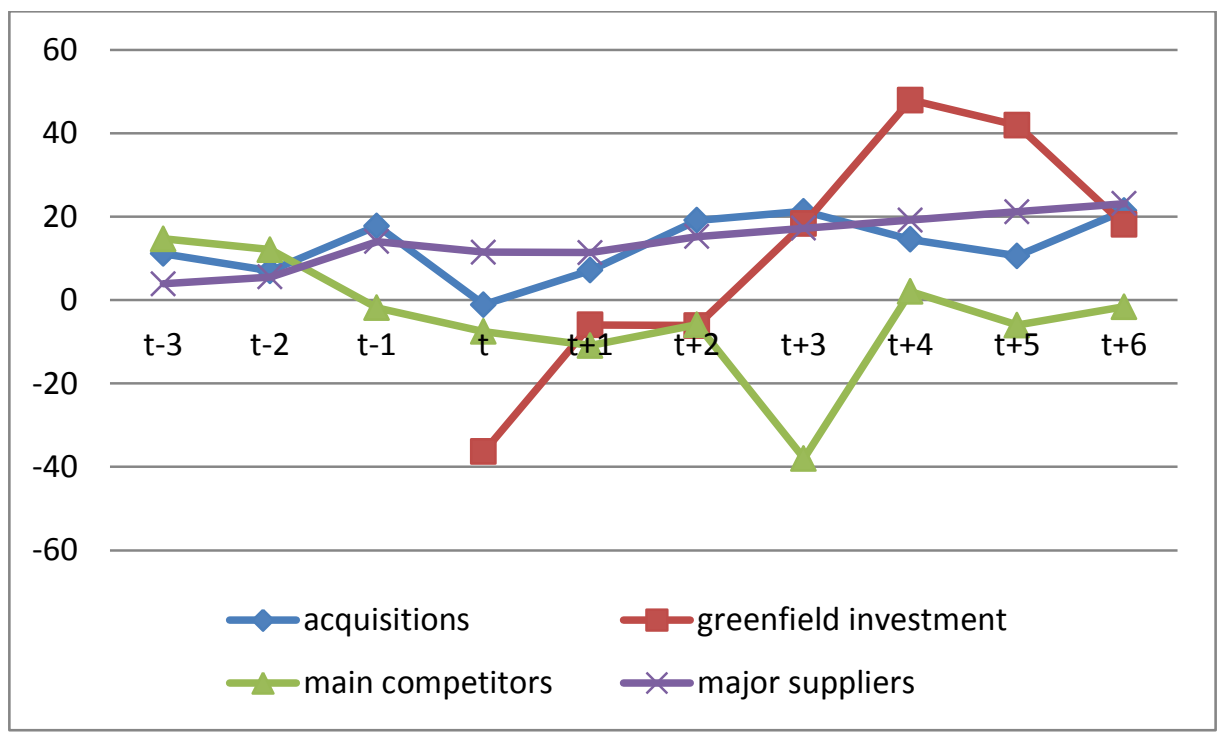

Source: Author's calculations based on data provided by the SBRA

In the case of green-field investments, there is a growing trend of ROE.In the case of Greenfield investments, there is a growing trend of ROE, especially after especially after third year from production start. From the figure it can be seen that the rate of return on equity in the case of green-field investment in the fourth and fifth year in relation to the base is by far the largest in comparison 
to other companies and has a value of over 40 , suggesting that it is a very fast returning companies.

In the case of the main competitors, there is a decreasing trend of ROE, especially after the entry of foreign companies into the market, since it generally has a negative value. Major suppliers on the other hand, have a moderate but steady increase in ROE, which highest value was recorded in the sixth year, 23.1. Based on the above, it can be concluded that the greenfield investments and major suppliers had the highest return on equity, somewhat weaker acquisitions while main competitors recorded losses especially after the third year of the entry of foreign companies into the market.

Figure 8 . The average change in the rate of return on assets

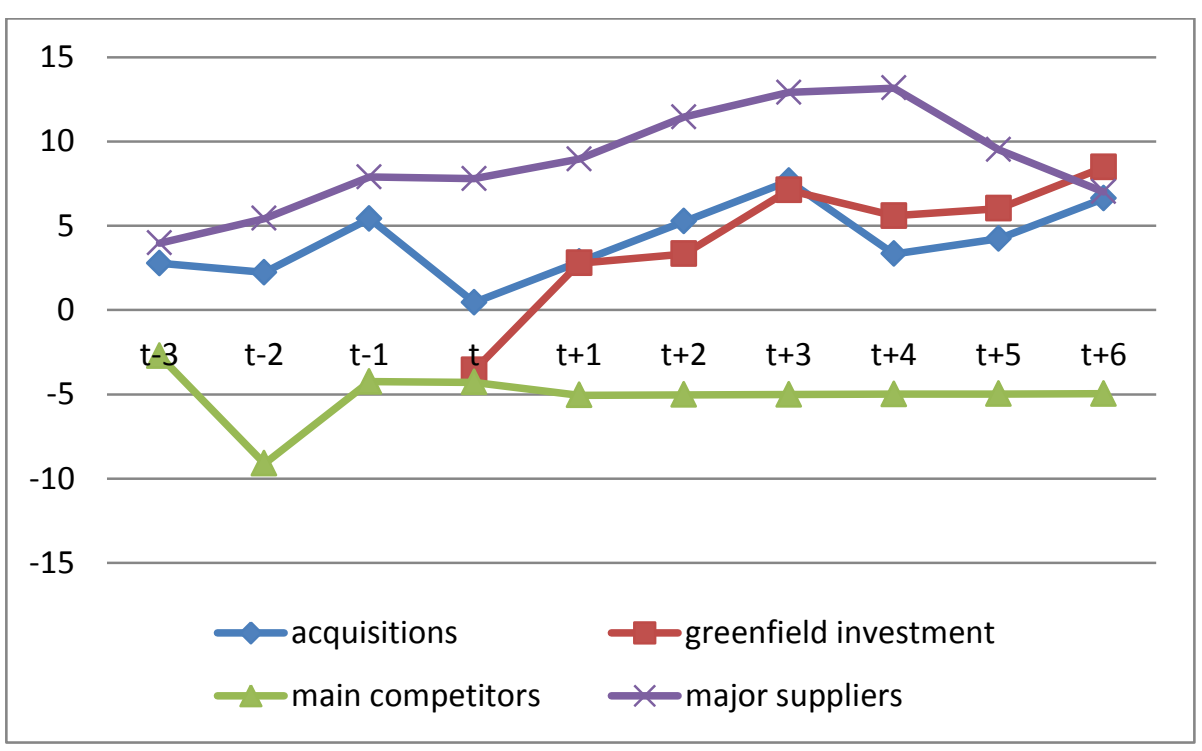

In the case of the average change in the rate of return on assets (ROA), the results are somewhat different in relation to the comparison with the average ROE. The main suppliers had the best result as compared to their assets (which is quite small compared to companies with which they are compared) they had higher profit compared to green-field investment and acquisitions. As in the case of ROE, ROA in the case of main competitors had the lowest values. 
Boljanović S., Hadžić M: Impact of Foreign Direct Investments on Serbian Industry

\section{Conclusion}

The study proved that FDI had a positive effect on the growth of Serbian exports. When all the variables were included in the model, the increase in the FDI stock of $1 \%$ leads to an increase in exports of $0,035 \%$. When gross investments are excluded from the model, the impact of FDI is even more powerful, the increase in the FDI stock of $1 \%$ leads to an increase in exports of $0.149 \%$. Results of previously performed correlation analysis indicate the existence of a strong positive correlation between FDI and exports (Pearson correlation coefficient is 0.619 ).

The positive impact of FDI on exports is also manifested through productivity when FDI and gross capital formation are not included in the model. Increase in productivity of $1 \%$ leads to an increase in exports of $1.294 \%$. It seems that the productivity is the channel through which FDI had impact on better export performance of Serbian industry. This is confirmed by research at the micro level when acquisitions, green - field investments, main competitors and major suppliers recorded productivity growth.

Gross fixed capital formation had a strong impact on exports (increase in gross investment of $1 \%$ leads to an increase in exports of $0.240 \%$ with significance level of $1 \%$ ), while real effective exchange rate haven't had a major impact on exports, and unit labour costs were statistically significant in the model in which FDI were not included.

The research conducted at the company level indicates the existence of horizontal and vertical spillover effects. Positive spillover effects are slight increase in the number of employees of major suppliers, sales growth of major suppliers, labour productivity growth of main competitors and major suppliers, the increase in net profit, the rate of return on equity and the rate of return on assets of major suppliers. It can be concluded that FDI through vertical spillover effects had a positive effect on major suppliers.

Negative spillovers are reflected in the reduction of number of employees of main competitors, crowding out of the market and a drop in revenues from sales, net profits, the rate of return on equity and the rate of return on assets of competitors of foreign affiliates. It can be concluded that FDI have led to significant displacement from the market of main competitors.

Thus, FDI have a positive impact on the growth of Serbian exports and labour productivity, as well as a positive impact on the major suppliers. In addition, the research on the micro level has shown the tendency of decrease in the number of employees, productivity growth, increase in sales revenue, net profit, the rate of return on equity and the rate of return on assets in the case of acquisitions. This suggests that the change of ownership and availability of 
specific resources that foreign companies possess had a positive impact on privatized companies. In the case of green-field investments the trend of growth of number of employees, productivity, sales revenue, net profit, the rate of return on equity and the rate of return on assets was recorded. This gives us sufficient grounds to accept the general hypothesis, FDI have had a positive impact on Serbian manufacturing industry.

It is important for the decision makers that the research pointed that export performance of the Serbian manufacturing industry can be improved by attracting more FDI into this sector. In order to achieve this more active investment-promoting policy measures are needed. However, the policy makers should also try to target specific export-oriented green-field FDI and implement other measures that make potential positive spillover effects more probable. Basically, host countries may condition FDI incentives on mandatory measures or use the incentives to encourage investors to behave in a certain way. Performance requirements may include export orientation of production, which have already been mentioned, but they may relate to the training of local workers and technology transfers, as well. The most important measures are those that strengthen the host countries' own capabilities. Only countries with high level of human capital have enough absorptive capacity to profit from high techology and procedures disseminated by foreign investors.

The contribution of the research can be summarized as follows: the analysis of the influence of FDI to Serbian manufactuiring was conducted on the macro and micro level. On the macro level the mixed model was used with method of the least squares, with fixed effects, on the sample of 23 brances in manufacturing in the period 2009-2013. On the micro level the sample were 40 largest foreign companies in manufacturing in order to identify horizontal and vertical spillover effects.

If one talks about limits of the research than such limits can be pointed: no clear answer and precise solution how to channel FDI to the most qualitative one e.g. green - field investemsnts into manufacturing. From this, one can see that possible topic for further investigation can be the investigation of the main factors for FDI attraction in manufacturing. Also important could be to envisage non - economic factors behind FDI, like historical, cultural, political and social factors. 
Boljanović S., Hadžić M: Impact of Foreign Direct Investments on Serbian Industry

\section{References}

Aitken, B., Hanson, G.H., \& Harrison, A.E. (1997). Spillovers, foreign investment, and export behaviour. Journal of International Economics, 43, 103-132.

Basile, R., Castellani, D., \& Zanfei, A. (2003). Location choices of multinational firms in Europe: The role of national boundaries and EU policy. International Trade, Econ WPA.

Blalock, G., \& Simon, H. (2009). Do all firms benefit equally from downstream FDI?, The moderating effect of local suppliers' capabilities on productivity gains. Journal of International Business Studies, 40(7), 1095-1112. September, Palgrave Macmillan.

Blomstrom, M., \& Persson, H. (1983). Foreign investment and spillover efficiency in an underdeveloped economy: Evidence from the Mexican manufacturing industry. World Development, 11(6), 493-501. Elsevier June..

Blomstrom, M., \& Kokko, A. (1997). How foreign direct investment affect host countries. World Bank Policy Research Working Paper, 1745,

Carstensen, K., \& Toubal, F. (2004). Foreign direct investment in Central and Eastern European countries: A dynamic panel analysis. Journal of Comparative Economics, 32(1), 3-22.

Caves, R.E. (1974). Multinational Firms, Competition, and Productivity in Host-Country Markets. Economica, 41(162), doi:10.2307/2553765

Djankov, S., \& Hoekman, S. (1996). Intra-Industry Trade, Foreign Direct Investment, and the Reorientation of Eastern European Exports. Policy Research Working Paper, 1652, Washington, D. C. The World Bank..

Girma, S. (2005). Absorptive Capacity and Productivity Spillovers from FDI: A Threshold Regression Analysis*. Oxford Bulletin of Economics and Statistics, 67(3), 281-306. doi:10.1111/j.1468-0084.2005.00120.x

Globerman, S. (1979). Foreign Direct Investment and 'Spillover' Efficiency Benefits in Canadian Manufacturing Industries. Canadian Journal of Economics, Canadian Economics Association, pages, 12(1), 42-56. February.

Gorg, H., \& Strobl, E. (2004). Foreign Direct Investment and Local Economic Development: Beyond Productivity Spillovers, Globalisation. Productivity and Technology Research Paper, 2004/11,

Javorcik, B., Saggi, K., \& Spatareanu, M. (2004). Does it matter where you come from?, Vertical spillovers from foreign direct investment and the nationality of investors. Policy Research Working Paper Series, 3449, The World Bank.

Kinoshita, Y. (2000). R\&D and Technology Spillovers via FDI: Innovation and Apsorptive Capacity. William Davidson Institute, Working Paper, 349,

Kokko, A., Tansini, R., \& Zejan, M. (1994). Productivity Spillovers from FDI in the Uruguayan Manufacturing Sector. SSE/EFI Working Paper Series in Economics and Finance, 2, Stockholm School of Economics.

Konings, J. (2000). The Effects of Direct Foreign Investment on Domestic Firms: Evidence from Firm Level Panel Data in Emerging Economies. CEPR Discussion Papers, 2586,

Lall, S. (1980). Vertical Interfirm Linkages in LDCs: An Empirical Study. Oxford Bulletin ofEconomics and Statistics, 42, 203-226. 
Boljanović S., Hadžić M: Impact of Foreign Direct Investments on Serbian Industry

Merlevede, B., \& Schoors, K. (2007). FDI and the Consequences: Towards more complete capture of spillover effects. William Davidson Institute Working Papers Series, wp886, William Davidson Institute at the University of Michigan.

Schoors, K., \& van der Tol, B. (2002). Foreign direct investment spillovers within and between sectors: Evidence from Hungarian data. Working Papers of Faculty of Economics and Business Administration, Ghent University, Ghent.

Sun, H. (2001). Foreign Direct Investment and Regional Export Performance in China. Journal of Regional Science,41(2), 317-336. doi:10.1111/00224146.00219

Škudar, A. (2004). Pregled i analiza iz ravnih ulaganja u Republiku Hrvatsku. In Pregledi. Zagreb: Hrvatska Narodna Banka. P-16.

Tytell, I., \& Yudaeva, K. (2005). The Role of FDI in Eastern Europe and New Independent States: New Channels for the Spillover Effect. Centro Stydi Luca d'Agliano Development Studies Working Paper, 217,

Vukšić, G. (2005). Impact of foreign direct investment on Croatian manufacturing exports, Financial Theory and Practice. Institute of Public Finance, pages, 29(2), 131-158.

Zhang, K.H., \& Song, S. (2000). Promoting Exports: The Role of Inward FDI in China. China Economic Review, 11(4), 385-396.

Retrieved from http://www.apr.gov.rs/

Retrieved from http://www.nbs.rs/

Retrieved from http://webrzs.stat.gov.rs/ 
Boljanović S., Hadžić M: Impact of Foreign Direct Investments on Serbian Industry

\section{Appendix}

Table 1. The average values of variables according to industry

\begin{tabular}{|c|c|c|c|c|c|c|c|c|c|c|c|c|c|c|c|}
\hline NCE & & Export & & & I stock & & & ductiv & & Unit I & labor c & sts & Gros & $s$ investr & nent \\
\hline A & $\begin{array}{c}\text { Average } \\
\text { value }\end{array}$ & \begin{tabular}{|} 
Std. \\
dev.
\end{tabular} & $\begin{array}{c}\text { Average } \\
\text { growth }\end{array}$ & $\begin{array}{c}\text { Average } \\
\text { value }\end{array}$ & $\begin{array}{l}\text { Std. } \\
\text { dev. }\end{array}$ & $\begin{array}{c}\text { Average } \\
\text { growth }\end{array}$ & $\begin{array}{c}\text { Average } \\
\text { value }\end{array}$ & $\begin{array}{l}\text { Std. } \\
\text { dev. }\end{array}$ & $\begin{array}{c}\text { Average } \\
\text { growth }\end{array}$ & $\begin{array}{c}\begin{array}{c}\text { Average } \\
\text { value }\end{array} \\
\end{array}$ & $\begin{array}{l}\text { Std. } \\
\text { dev. }\end{array}$ & $\begin{array}{c}\text { Average } \\
\text { growth }\end{array}$ & $\begin{array}{c}\text { Average } \\
\text { value }\end{array}$ & $\begin{array}{l}\text { Std. } \\
\text { dev. }\end{array}$ & $\begin{array}{c}\text { Average } \\
\text { growth }\end{array}$ \\
\hline 15 & 76430 & 8367 & 4.49 & 51,473 & 35,40 & 39.93 & 107.97 & 10.96 & -0.79 & 86.13 & 14.24 & -0.60 & 20355 & 10117 & -6.88 \\
\hline 16 & 2246 & 1174 & 34.04 & 11,046 & 1,231 & 2.66 & 84.18 & 18.76 & 1.86 & 137.06 & 42.00 & 10.23 & 1419 & 1029 & 46.10 \\
\hline 17 & 8501 & 3673 & 3.71 & 11,373 & 4,728 & 34.99 & 157.95 & 50.77 & 21.80 & 139.06 & 43.06 & 19.82 & 3513 & 4763 & 25.24 \\
\hline 18 & 24465 & 6505 & 14.91 & 2,244 & 1,533 & 32.38 & 110.76 & 15.57 & 1.65 & 166.90 & 38.36 & 13.70 & 979 & 616 & 45.58 \\
\hline 19 & 14804 & 2760 & 7.85 & 234 & 106 & 23.48 & 132.50 & 19.04 & 6.28 & 101.62 & 6.53 & 0.58 & 816 & 782 & 116.6 \\
\hline 20 & 12472 & 3484 & 13.24 & 5,573 & 3,832 & 68.72 & 128.52 & 24.55 & 5.13 & 131.86 & 21.50 & 9.75 & 3484 & 2844 & 52.31 \\
\hline 21 & 14852 & 4962 & 13.72 & 2,183 & 744 & 19.82 & 153.03 & 40.96 & 5.74 & 123.08 & 43.05 & 17.22 & 2918 & 1705 & 21.29 \\
\hline 22 & 2311 & 1043. & 9.93 & 2,088 & 768 & 20.12 & 115.93 & 62.57 & 12.38 & 91.54 & 20.94 & 8.89 & 1877 & 1999 & 13.19 \\
\hline 23 & 9917 & 3183 & 13.67 & 1,868 & 869 & 134.2 & 262.84 & \begin{tabular}{|l|}
179.8 \\
\end{tabular} & 34.98 & 62.21 & 30.06 & -15.48 & 10783 & 8303 & 67.30 \\
\hline 24 & 38418 & 7927 & 6.80 & 41,299 & 3,692 & 0.99 & 114.22 & 12.08 & 0.51 & 100.56 & 8.78 & 3.22 & 6028 & 3779 & -0.22 \\
\hline 25 & 45329 & 16496 & 15.39 & 13,759 & 6,451 & 24.78 & 156.64 & 40.97 & 13.43 & 88.84 & 8.09 & -2.64 & 3917 & 2706 & -6.21 \\
\hline 26 & 9272. & 1218 & 0.54 & 5,452 & 2,436 & 22.25 & 143.51 & 23.08 & 6.73 & 86.77 & 11.67 & 1.26 & 5303 & 2871 & 12.68 \\
\hline 27 & 87599 & 18175 & -2.86 & 26,699 & 19,52 & 56.32 & 64.69 & 34.76 & 12.18 & 271.82 & 213.5 & 90.13 & 3918 & 2474 & 0.50 \\
\hline 28 & 29094 & 11280 & 24.65 & 10,413 & 3,850 & 16.29 & 123.54 & 20.16 & 4.48 & 104.95 & 10.41 & 3.38 & 5520 & 2593 & 21.87 \\
\hline 29 & 30326 & 7344 & 11.40 & 4,780 & 1,558 & 21.29 & 157.25 & 33.93 & 10.90 & 90.58 & 12.38 & 2.09 & 5704 & 2580 & 17.15 \\
\hline 30 & 3907 & 1155 & 17.46 & 300 & 169 & 72.20 & 132.54 & 16.94 & 4.83 & 86.38 & 10.36 & -0.63 & 1280 & 747 & 38.45 \\
\hline 31 & 33263 & 13731 & 23.53 & 2,147 & 1,006 & 24.32 & 127.77 & 21.2 & 5.08 & 94.02 & 10.65 & -1.33 & 1207 & 600 & 6.40 \\
\hline 32 & 4616 & 1055 & 13.38 & 598 & 122 & 8.08 & 121.95 & 17.7 & 4.38 & 112.99 & 21.28 & 6.09 & 645 & 414 & 14.47 \\
\hline 33 & 4971 & 1235 & 15.54 & 1,928 & 387 & 7.03 & 128.27 & 25.7 & 3.02 & 103.95 & 24.40 & 7.23 & 2594 & 1876 & 38.96 \\
\hline 34 & 40487 & 55222 & 70.67 & 13,714 & 11,21 & 134.1 & 205.85 & 112.1 & 36.93 & 75.19 & 28.50 & -4.80 & 22515 & 29988 & 146.7 \\
\hline 35 & 10393 & 3730 & 24.43 & 1,396 & 763 & 58.00 & 256.81 & 93.77 & 25.78 & 67.27 & 22.13 & -6.07 & 474 & 432 & 74.25 \\
\hline 36 & 12169 & 2787 & 11.40 & 3,431 & 1,174 & 19.10 & 126.27 & 26.37 & 3.32 & 107.10 & 23.85 & 8.45 & 1769 & 1428 & 11.16 \\
\hline 3 & 7002 & 2413 & 14.34 & 1,305 & 511 & 22.50 & 128.00 & 23.13 & 3.07 & 118.29 & | 26.87 & 10.53 & 586 & 362 & 8.76 \\
\hline
\end{tabular}

